\title{
HORMONE EXCRETION IN LIVER DISEASE ${ }^{1}$
}

\author{
By F. C. DOHAN, E. M. RICHARDSON, L. W. BLUEMLE, JR., AND \\ P. GYORGY
(From the Department of Medicine and The Nutritional Laboratory of the Department of Pediatrics of the Medical School of the University of Pennsylvania, Philadelphia, and The Army Hepatic and Metabolic Center of the Valley Forge Army Hospital, Phoenixville, Pa.)

(Submitted for publication January 15, 1952; accepted March 17, 1952)

Gynecomastia, cutaneous spider nevi, testicular atrophy, and loss of libido are frequently found in men with chronic liver disease. The clinical aspects of the subject have recently been reviewed (1). On the basis of studies of urinary estrogen excretion (2), these changes have been attributed to increased levels of estrogens, particularly unconjugated estrogens presumably resulting from decreased conjugation in the diseased liver. This presumption is based on abundant evidence indicating that the liver of certain laboratory animals may "inactivate" estrogens (3), and that
Figure 1 shows in diagrammatic fashion some of the factors usually considered in the production and metabolism of estrogens in man. Several authors $(3,8-10)$ have recently reviewed the metabolism of estrogens, therefore the large amount of data supporting this scheme need not be cited here. The importance of the liver in the metabolism of estrogens is apparent. It will be noted that, if production is constant, the estrogen level of the blood may presumably be modified through: (a) excretion of the material in the urine and bile (and through the intestinal wall?) some being

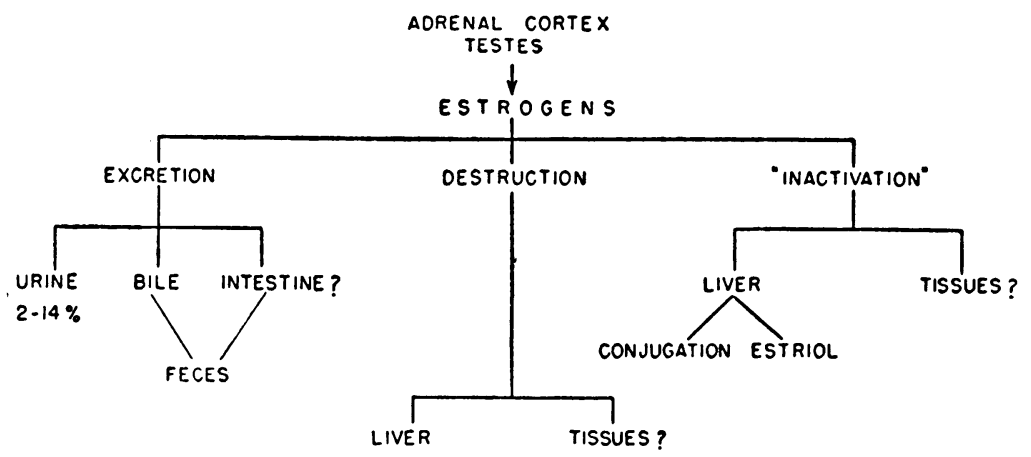

Fig. 1. Estrogen Metabolism

This figure outlines some of the factors that have been given consideration in discussions of the metabolism of estrogens.

the subcutaneously injected conjugated estrogens are less "potent" than the free forms (4). However, more recent evidence indicates the role of the human liver in estrogen inactivation is less impressive (5) and that the relative inactivity of conjugated estrogens is not apparent when tested at the target tissue level $(6,7)$.

\footnotetext{
1 This investigation was conducted under the auspices of the Commission on Liver Disease, Armed Forces Epidemiological Board, and supported in part by the Office of The Surgeon General, Department of the Army, Washington, D. C.
}

lost in the feces despite an enterohepatic circulation, $(b)$ destruction of the estrogen molecule, and $(c)$ production of conjugated estrogens and of estriol, forms that are usually considered "less potent."

With these concepts in mind, we have analyzed the urinary excretion of the unconjugated and conjugated forms of the "estradiol," "estrone," and "estriol" fractions as well as gonadotrophins and neutral 17-ketosteroids for one or more periods in five normal men and 17 men with diffuse hepatic disease. The results are presented in 
relation to: (a) the severity of the liver disease, (b) the standard liver function tests, (c) the effect of liver disease on estrogen metabolism, $(d)$ the inter-relationships of urinary hormone excretion, and $(e)$ the presence or absence of gynecomastia, cutaneous spider nevi, palmar erythema, testicular atrophy, and loss of libido. In addition, data concerning the urinary excretion of unconjugated neutral 17-ketosteroids, the ketonic and non-ketonic steroid fractions, and the urinary corticoids are briefly presented.

\section{MATERIALS AND METHODS}

Clinical material. Of the special group of 17 patients with diffuse liver disease whose urine was subjected to estrogen fractionation studies, 15 were studied in the Hepatic and Metabolic Section at the Valley Forge Army Hospital and two were studied on the Medical Wards of the Hospital of the University of Pennsylvania. Results reported under miscellaneous observations were, in part, obtained on patients other than those in this special group. These patients were also studied at these two hospitals. Special aspects of methods concerning them will be mentioned in the text. In most instances, patients were selected for this study because of the severity of the symptoms or the presence of gynecomastia, testicular atrophy or spider nevi. The five controls were healthy men without known liver disease.

Chronic hepatitis was diagnosed in four of the subjects, subsiding acute hepatitis in one, "portal cirrhosis" in 11 , and one had severe hemochromatosis. The term chronic hepatitis, as used in this paper, indicates that the patient had a history compatible with that of acute viral hepatitis, with "recurrence" or incomplete recovery six months or more after the acute episode. The term "portal cirrhosis" is used to indicate a diffuse hepatic fibrosis in men usually associated with a history of alcoholism, but without a history suggestive of acute viral hepatitis.

Frequent clinical observations and tests of liver function and a needle biopsy of the liver were obtained. The severity of the liver disease was then classified as 0 to 4 plus in each case. This classification was made by a numerical evaluation of: (a) severity of symptoms and physical findings, $(b)$ results of liver function tests, and $(c)$ histologic appearance of liver biopsies.

The liver function tests were done by standard technics and those used for the above classification included total serum bilirubin, thymol turbidity, 24 hour cephalin cholesterol flocculation, prothrombin activity, percentage of cholesterol in the esterified form, serum albumin and the measurement of bromsulphalein retention if the serum bilirubin was less than $1.3 \mathrm{mg} . / 100 \mathrm{ml}$. These values were scored 0 to 4 plus and averaged as were the histologic and clinical criteria of liver disease. The final estimate of the severity of the disease was then based on an average of the estimate in each of the three categories.
The grade of gynecomastia was estimated as 1 to 4 plus on the basis of unilateral or bilateral involvement, the size of the firm "button" of tissue beneath the areola, and the presence or absence of tenderness.

Cutaneous spider nevi have been classified as 1 to 4 plus according to number, size, presence or absence of pulsations, and location. Nevi located about the neck and face were not considered as significant as those located about the trunk and extremities, since small spider nevi are frequently found in the former sites in "normal" individuals.

Scrotal contents of all patients were palpated to determine testicular size and consistency. Measurements of length and width were obtained with the surrounding scrotal wall thinned maximally without distortion of testicular dimensions. Testicular atrophy was considered present when overall length measured less than $4.5 \mathrm{~cm}$. and overall width less than $3 \mathrm{~cm}$. The three patients classified as having marked atrophy had soft testes considerably smaller than the lower limits of normal.

Hormone assays. Urine collections were made under the supervision of trained personnel. In a few instances, the periods of collection were three days; all others were six to 22 days. This quantity of material permits considerably more accurate bioassays than a single 24 hour collection and, in addition, provides a more representative sample. All urine was preserved with toluene and prompt refrigeration. The few daily urine collections with $\mathrm{pH}$ of 7 or greater were acidified to $\mathrm{pH} 6$ to 6.5 shortly after the 24 hour collection was completed. Extractions were completed within 48 hours of the last day of the period. Aliquots were taken from the daily urine specimens so that a representative sample was obtained for gonadotrophins and 17-ketosteroids. Daily creatinine determinations were made as a check on the accuracy of the urine collections in 17 of the total of 26 periods. The term "hormone" in this presentation, following conventional usage, includes hormone metabolites.

Estrogens. The unconjugated (free) estrogens were extracted for 48 hours at $\mathrm{pH} 6-7$ using the continuous ether extraction method of Wilson, Grauer, and Saier (11). After hydrolysis for one hour at $95^{\circ} \mathrm{C}$. with $5 \%$, by volume, of concentrated sulfuric acid, the conjugated form of the estrogens was similarly extracted. These two extracts were then separated into the "estrone," "estradiol," and "estriol" fractions by the method of Friedgood, Garst, and Haagen-Smit (12). This procedure was modified to include the Mather (13) technic of adjusting the $\mathrm{pH}$ of aqueous solutions of estrogen to pH 9 before extractions with ether. Thus, six fractions were obtained; representing the free and the conjugated forms of the "estrone," "estradiol," and "estriol" fractions.

Bio-assays of the estrogen fractions were performed in estrone primed, pure strain, castrate female white mice (CFW 1). Estrone and estradiol fractions were given each morning, and the estriol fraction twice daily, subcutaneously in corn oil for three days. Vaginal smears were made at 72 and 96 hours after the first injection and were stained with methylene blue. After preliminary as- 
say of each unknown employing six or more mice, a "final" 2-point assay was made using from four to 40 mice (mean $=13$ ). The number used depended upon the amount of "estrogen" available in the "unknown" as indicated by the preliminary assay. The bio-assay of each group of unknowns of the same fraction was always accompanied by a two-dose level control assay ( 40 mice) of the appropriate standard estrogen, i.e., crystalline estrone, estradiol, or estriol. The quality control test of Simon (14) allowed us to infer that the results of these control assays with any single crystalline estrogen were homogeneous because the subsample values fell satisfactorily within the 0.01 control lines. In addition, the responses for estrone were fitted to a binomial curve and again the discrepancies between the theoretical and observed distributions were attributable to chance variation $(P=$ 0.18 for the low dose, $P=0.75$ for the high dose). Since there was no statistically valid demonstration of significant variation in the sensitivity of the mice, the results of all controls were pooled. This lack of variation in sensitivity of the mice is not in agreement with the experience of Emmens (15) and may be due to differences in technical details. The results of the assays of the unknowns have been compared with the pooled results of the standard. The relatively small estimated error of the standard is reflected in the estimated error (limits of confidence) of the unknowns. The potency estimates and the limits of confidence in $39 \%$ of the 156 assays were calculated by the probit analysis method of Emmens (16). In these instances, sufficient estrogen was usually present in the urine so that a two-dose level assay, using 10 to 20 mice per point, could be performed. The mean of the dose response slope (b) of the urine extracts was approximately 5.7. That of the crystalline standards was 6.7. Parallelism of the dose response lines of the unknown to the standard was assumed in those few instances where statistical evidence indicated more than one chance in 20 that this was not so. The limits of confidence of all assays have been calculated at the $95 \%$ confidence level. For those assays in which probit analysis was not employed, the limits of confidence were calculated from Mainland's Table of Confidence Limits for Enumeration Data (17).

"Estrone Equivalent" is the term used to indicate estrogenic effect expressed as the amount of crystalline estrone required to produce a similar effect under similar conditions. We have calculated it as the sum of the median values (or the potency estimates of the probit analysis data) for each of the estrogen fractions expressed in terms of the amount of estrone with equivalent estrogenic activity. This is obtained from the relationship of the $\mathrm{ED}_{\text {so }}$ of estradiol $(0.043 \mu \mathrm{g}$.) and estriol $\left(0.289 \mu \mathrm{g}\right.$.) to estrone $(0.142 \mu \mathrm{g}$. $)$. The $\mathrm{ED}_{\mathrm{so}}$ is that amount of each of the crystalline estrogens necessary to produce full cornification of the vaginal smear in $50 \%$ of the mice used in the control assays. The term total estrogens indicates the sum of the estrone equivalents of the free and conjugated forms of all three fractions.

Critique of method for determination of estrogens.
Since the separation and determination of the estrogen fractions is a difficult task about which there is considerable difference of opinion, we have extracted and analyzed one 22 day collection of urine (patient No. 1) in duplicate. Each daily specimen was divided into halves (A and B) and aliquots taken from each in the usual fashion for gonadotrophins and 17-ketosteroids. The estrogen content calculated from the median values of the confidence limits for each fraction (or the potency estimates in the case of probit analysis) is given below.

\begin{tabular}{|c|c|c|c|c|c|c|}
\hline \multirow{3}{*}{ Specimen } & \multicolumn{6}{|c|}{ Mg. per 24 hours } \\
\hline & \multicolumn{2}{|c|}{ Estrone } & \multicolumn{2}{|c|}{ Estradiol } & \multicolumn{2}{|c|}{ Estriol } \\
\hline & Conj. & Free & Conj. & Free & Conj. & Free \\
\hline $\begin{array}{l}\text { A } \\
\text { B } \\
\text { Average } \\
\text { Deviation from aver. } \\
\text { \% deviation from aver. }\end{array}$ & $\begin{array}{l}0.51 \\
\text { Lost }\end{array}$ & $\begin{array}{l}0.36 \\
0.29 \\
0.325 \\
0.035 \\
10.8 \%\end{array}$ & $\begin{array}{l}0.18 \\
0.17 \\
0.175 \\
0.005 \\
2.9 \%\end{array}$ & $\begin{array}{c}0.06 \\
0.08 \\
0.07 \\
0.01 \\
14.3 \%\end{array}$ & $\begin{array}{l}1.80 \\
1.76 \\
1.78 \\
0.02 \\
1.1 \%\end{array}$ & $\begin{array}{c}0.40 \\
0.50 \\
0.45 \\
0.05 \\
11.1 \%\end{array}$ \\
\hline
\end{tabular}

In addition, $4,500 \mathrm{ml}$. of urine, representing that excreted during 115 hours by normal control IV, were extracted twice and $30 \mu \mathrm{g}$. of estrone were added. One-half of this twice-extracted urine was subjected to hydrolysis and the entire fractionation procedure; the other half was simply rehydrolyzed and extracted with ether and a bioassay performed. By this latter procedure, estrogenic activity equivalent to $72 \%$ of that of the added estrone was found. The bio-assay of the "estrone," "estradiol," and "estriol" fractions showed estrogenic activity of approximately $41 \%, 13 \%$, and $10 \%$, respectively, of that of the added estrone. This indicates incomplete separation of the small amount of estrone added to the urine. Further evidence that our extraction procedure extracts approximately $60-70 \%$ of the small amount of extractable estrogen present in male urine is afforded by the fact that the second extraction of the original urine (before addition of estrone) yielded additional estrogenic material. That extracted on the first extraction represented $66 \%$ of the total of the two.

It is concluded from these studies that reasonable agreement was obtained in the duplicate analyses and that recovery and fractionation is adequate to demonstrate major quantitative and qualitative variations. The relatively small calculated error of the duplicates is due, in part, to the use of the pooled values for the controls with its considerably smaller error than that of a single control assay.

Urinary gonadotrophin excretion. Urinary gonadotrophins were precipitated by alcohol and extracted by a modification of the dialysis method of Klinefelter, Albright, and Griswold (18). The bio-assays were performed by measuring the increase in uterine weight of 8 to $10 \mathrm{gm}$. pure strain immature female mice. After preliminary assays, four mice per dose level were used for final assay. One mouse unit of "gonadotrophin" is considered to be present if the mean uterine weight of the injected mice is increased $100 \%$ above the mean uterine 
TABLE I

Summary: hormone excretion in men with liver disease

\begin{tabular}{|c|c|c|c|c|c|c|c|c|c|c|c|c|}
\hline $\begin{array}{l}\text { CASE } \\
\text { NO. }\end{array}$ & $A G E$ & DIAGNOSIS & $\begin{array}{l}\text { DURATION } \\
\text { OF } \\
\text { SYMPTOAS }\end{array}$ & $\begin{array}{l}\text { GYNECO } \\
\text { MASTIA }\end{array}$ & $\begin{array}{c}\text { SPIDERR } \\
\text { NEVI }\end{array}$ & $\begin{array}{l}\text { PALMAR } \\
\text { ERYTHEDA }\end{array}$ & $\begin{array}{l}\text { TESTIC. } \\
\text { ATROPHY }\end{array}$ & $\begin{array}{c}\text { LOSS } \\
\text { OF } \\
\text { LIBIDO }\end{array}$ & $\begin{array}{l}\text { ESTR } \\
\text { FREE }\end{array}$ & $\begin{array}{l}\text { ENS* } \\
\text { FREE \& } \\
\text { CONJ. }\end{array}$ & $\begin{array}{l}\text { 17-KKETO } \\
\text { STEROIDS }\end{array}$ & $\begin{array}{l}\text { GONADO } \\
\text { TROPHIC } \\
\text { HORMOATS }\end{array}$ \\
\hline & IRS. & & MO. & & & CONTROA & & & \multicolumn{2}{|c|}{$\mu \mathrm{G} / 24 \mathrm{HRS}$} & $\mathrm{MG} / 24 \mathrm{KR}$ & M.U./24 KR. \\
\hline$\underset{I I I}{I I}$ & $\begin{array}{l}25 \\
27 \\
27 \\
28 \\
37\end{array}$ & $\begin{array}{l}\text { NORMAI } \\
\text { NORMAI } \\
\text { NORMAI } \\
\text { NORMAI } \\
\text { NORMAI }\end{array}$ & $\begin{array}{l}- \\
-\end{array}$ & $=$ & $=$ & $\begin{array}{l}- \\
- \\
-\end{array}$ & $=$ & 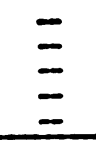 & $\begin{array}{l}1.4 \\
0.5 \\
0.8 \\
0.3 \\
0.2\end{array}$ & $\begin{array}{l}4.0 \\
2.9 \\
3.2 \\
2.9 \\
1.7\end{array}$ & $\begin{array}{r}16.2 \\
11.6 \\
10.0 \\
13.1 \\
9.1\end{array}$ & $\begin{array}{l}26 \\
16 \\
17 \\
28 \\
25\end{array}$ \\
\hline $\begin{array}{l}\text { Avor } \\
\text { S. E }\end{array}$ & $\begin{array}{l}28.8 \\
\text { of } \mathrm{M}\end{array}$ & $y x-37 y$ & & & & & & & $\begin{array}{l}0.6 \\
0.2 \\
\end{array}$ & $\begin{array}{r}2.9 \\
+0.4 \\
\end{array}$ & $\begin{array}{r}12.0 \\
+1.3\end{array}$ & $\begin{array}{r}22 \\
t 2\end{array}$ \\
\hline
\end{tabular}

\begin{tabular}{|c|c|c|c|c|c|c|c|c|c|c|c|c|}
\hline \multirow[b]{2}{*}{$\begin{array}{r}3 \\
4 \\
5 \\
12\end{array}$} & \multicolumn{12}{|c|}{ GRADE I IIVER DISEASE } \\
\hline & $\begin{array}{l}24 \\
26 \\
27 \\
43\end{array}$ & $\begin{array}{l}\text { AC. HEPAT. } \\
\text { CHR. HEPAT. } \\
\text { CHR. HEPAT. } \\
\text { PORT. CIRR. }\end{array}$ & $\begin{array}{r}5 \\
48 \\
11 \\
11\end{array}$ & $\begin{array}{c}H \\
0 \\
0 \\
H\end{array}$ & $4_{0}^{0}$ & $\begin{array}{l}0 \\
t \\
0\end{array}$ & $\begin{array}{l}0 \\
0 \\
0 \\
0\end{array}$ & $\begin{array}{l}0 \\
0 \\
0 \\
0\end{array}$ & $\begin{array}{l}0.8 \\
1.0 \\
0.5 \\
0.4\end{array}$ & $\begin{array}{r}12.3 \\
7.3 \\
3.9 \\
2.5 \\
\end{array}$ & $\begin{array}{l}4.0 \\
19.9 \\
13.8 \\
13.1\end{array}$ & $\begin{array}{l}- \\
21 \\
15\end{array}$ \\
\hline $\begin{array}{l}\text { Aver. } \\
\text { S. E. }\end{array}$ & $\begin{array}{l}30 \\
\text { of }\end{array}$ & $\left.x_{0}-43 x_{0}\right)$ & & & & & & & $\begin{array}{r}0.7 \\
\leqslant 0.1\end{array}$ & $\begin{array}{r}6.5 \\
+2.2\end{array}$ & $\begin{array}{r}12.17 \\
+\quad 3.3\end{array}$ & 18 \\
\hline
\end{tabular}

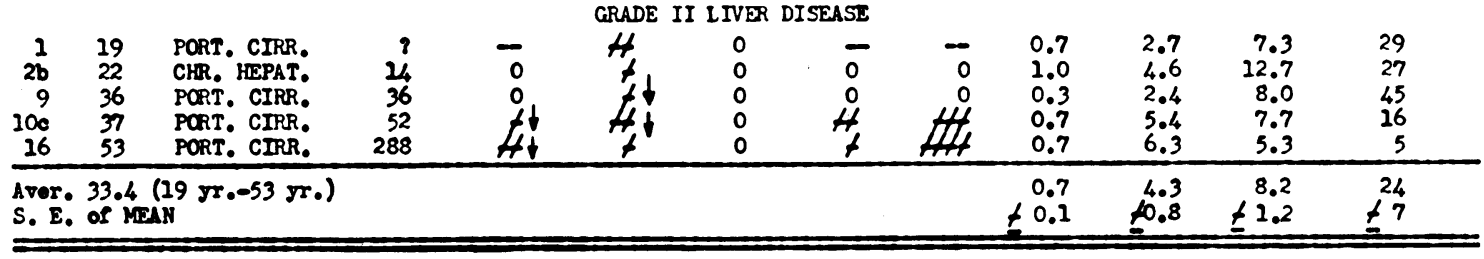

\begin{tabular}{|c|c|c|c|c|c|c|c|c|c|c|c|c|}
\hline \multirow[b]{2}{*}{$\begin{array}{r}6 \\
8 b \\
10 b \\
11 \\
13 \\
14\end{array}$} & \multicolumn{12}{|c|}{ GRADE III ITVA DISEASE } \\
\hline & $\begin{array}{l}32 \\
35 \\
37 \\
43 \\
46 \\
48\end{array}$ & $\begin{array}{l}\text { PORT. CIRR. } \\
\text { PORT. CIRR. } \\
\text { PORT. CIRR. } \\
\text { CHR. HIOPAT. } \\
\text { PORT. CIRR. } \\
\text { IEMMOCHROM. }\end{array}$ & $\begin{array}{r}26 \\
4 \\
49 \\
96 \\
48 \\
276\end{array}$ & $\begin{array}{l}0 \\
H_{1} \\
0 \\
0 \\
0\end{array}$ & $\begin{array}{l}0 \\
0 \\
1\end{array}$ & $\begin{array}{l}0 \\
0 \\
0 \\
4 \\
0 \\
?\end{array}$ & $\begin{array}{r}0 \\
H 4 \\
0 \\
0 \\
H H\end{array}$ & $\begin{array}{l}0 \\
\text { Ayt } \\
\text { क } \\
\text { Het }\end{array}$ & $\begin{array}{l}0.4 \\
0.3 \\
3.0 \\
1.9 \\
0.5 \\
1.9\end{array}$ & $\begin{array}{l}2.9 \\
5.3 \\
4.7 \\
5.8 \\
4.1 \\
2.7\end{array}$ & $\begin{array}{l}8.7 \\
8.8 \\
5.3 \\
7.8 \\
7.0 \\
8.0\end{array}$ & $\frac{35}{3}$ \\
\hline $\begin{array}{l}\text { Aver } \\
\text { S. E }\end{array}$ & 40.2 & $22 y \cdot 0-48 y$ & & & & & & & $\begin{array}{l}1.3 \\
0.5\end{array}$ & $\begin{array}{l}4.3 \\
0.5\end{array}$ & $\begin{array}{l}7.6 \\
0.5\end{array}$ & $\begin{array}{r}20 \\
+10\end{array}$ \\
\hline
\end{tabular}

\begin{tabular}{|c|c|c|c|c|c|c|c|c|c|c|c|}
\hline \multirow[b]{2}{*}{$\begin{array}{r}2 a \\
7 \\
8 a \\
10 a \\
15 \\
17\end{array}$} & \multicolumn{11}{|c|}{ GRADE IV ITVER DISEAST } \\
\hline & $\begin{array}{l}22 \\
34 \\
35 \\
37 \\
53 \\
60\end{array}$ & $\begin{array}{l}\text { CRR. HEPAT, } \\
\text { PQRT. CIRR, } \\
\text { PQRT. CIRR. } \\
\text { PQRT. CIRR. } \\
\text { PORT. CIRR, } \\
\text { PORT. CIRR. }\end{array}$ & $\begin{array}{r}14 \\
5 \\
3 \\
48 \\
288 \\
3\end{array}$ & Hy & $\begin{array}{l}0 \\
0 \\
0 \\
0 \\
0 \\
0\end{array}$ & $\begin{array}{r}0 \\
0 \\
0 \\
H 4 \\
H\end{array}$ & $\begin{array}{r}0 \\
? \\
44 \\
4 \\
? \\
?\end{array}$ & $\begin{array}{l}0.8 \\
4.3 \\
0.6 \\
0.3 \\
2.8 \\
2.3\end{array}$ & $\begin{array}{r}7.6 \\
10.6 \\
8.2 \\
2.6 \\
12.6 \\
6.4\end{array}$ & $\begin{array}{l}7.9 \\
8.9 \\
5.5 \\
5.1 \\
4.6 \\
6.0\end{array}$ & $\begin{array}{r}20 \\
21 \\
3 \\
18 \\
5 \\
17\end{array}$ \\
\hline $\begin{array}{l}\text { Siver } \\
\text { S. } 2\end{array}$ & 40.2 & $22 \mathrm{gr} \cdot-60 \mathrm{Ir}$. & & & & & & $\begin{array}{l}1.9 \\
0.6\end{array}$ & $\begin{array}{r}8.0 \\
1.4\end{array}$ & $\begin{array}{l}6.3 \\
0.7\end{array}$ & $\begin{array}{r}14 \\
+3\end{array}$ \\
\hline
\end{tabular}

In general, these patients were selected for study because of the presence of gynecomastia, testicular atrophy, or spider nevi. Eleven patients were considered to have portal cirrhosis; four, chronic hepatitis; one, subsiding acute hepatitis; and one, hemochromatosis. Patients have been grouped according to the severity of the liver disease (see Methods). Three were studied during more than one period. During the interval between urine collections, the severity of the liver disease changed. The sequence of the studies is indicated by the letters. Arrows pointing upward indicate increased severity, and those pointing downward indicate decreased severity.

* Estrogens are expressed in terms of estrone equivalent.

** Scrotal edema.

weight of the control mice. With but few exceptions, no assays are reported in which the increase in uterine weight was less than $37 \%$ or greater than $200 \%$ above the control. Results within these narrow limits were then calculated from a standard dose response curve which had been calculated from a 5-point assay using 12 mice per point injected with an extract of menopausal urine.

Critique of gonadotrophin method. An estimate of the reproducibility of this method was obtained from 20 duplicate assays. Fifteen were performed at the same time and in five instances, the precipitate was saved and 
re-assayed six months later. The average deviation from the mean of the duplicates was $7 \%$ and the greatest deviation was $14 \%$. In addition, a duplicate precipitation, extraction and assay were done on the collection from patient No. 1. The duplicates in this case varied $5 \%$ from their mean. It is concluded that the assay method as outlined is fairly accurate and consistent.

The total neutral 17-ketosteroids were determined by a modification of the Holtorff-Koch method (19) on an aliquot of the total collection or on an aliquot of each of three or more 24 hour urine specimens, and the results were averaged. Extractions were done with carbon-tetrachloride. Corticoids were extracted and determined as neutral lipid-soluble reducing substances by a modification of the method of Heard, Sobel, and Venning (20). Total ether extractable ketonic and non-ketonic steroids were determined by weighing these fractions after the Girard separation. The free (pre-hydrolysis) 17-ketosteroids were determined on the neutral fraction of the ether extract.

Statistical methods. Calculation of estrogen assays is indicated above. The analysis of the statistical significance of the difference of means was done by the pooled variance method described by Snedecor (21). Calcula- tions of the regression coefficients and their significance also followed the methods of this author. The term significant indicates that there is less than one chance in 20 $(P<0.05)$ that the regression or difference of means is due to chance variation. Highly significant indicates less than one chance in 100 .

\section{RESULTS}

\section{Hormone excretion and severity of liver disease}

Table I lists certain clinical data and the values for the urinary excretion of the free (unconjugated) and total (free plus conjugated) estrogens, 17-ketosteroids, and gonadotrophins. Patients have been grouped into four grades according to the severity of the liver disease as judged by the numerical system detailed in Methods.

In 17 of the 21 periods (14 men) the 17ketosteroid excretion was lower than the lowest normal value, while in six periods (six men) the free form of estrogen, and in 14 periods (11 men)

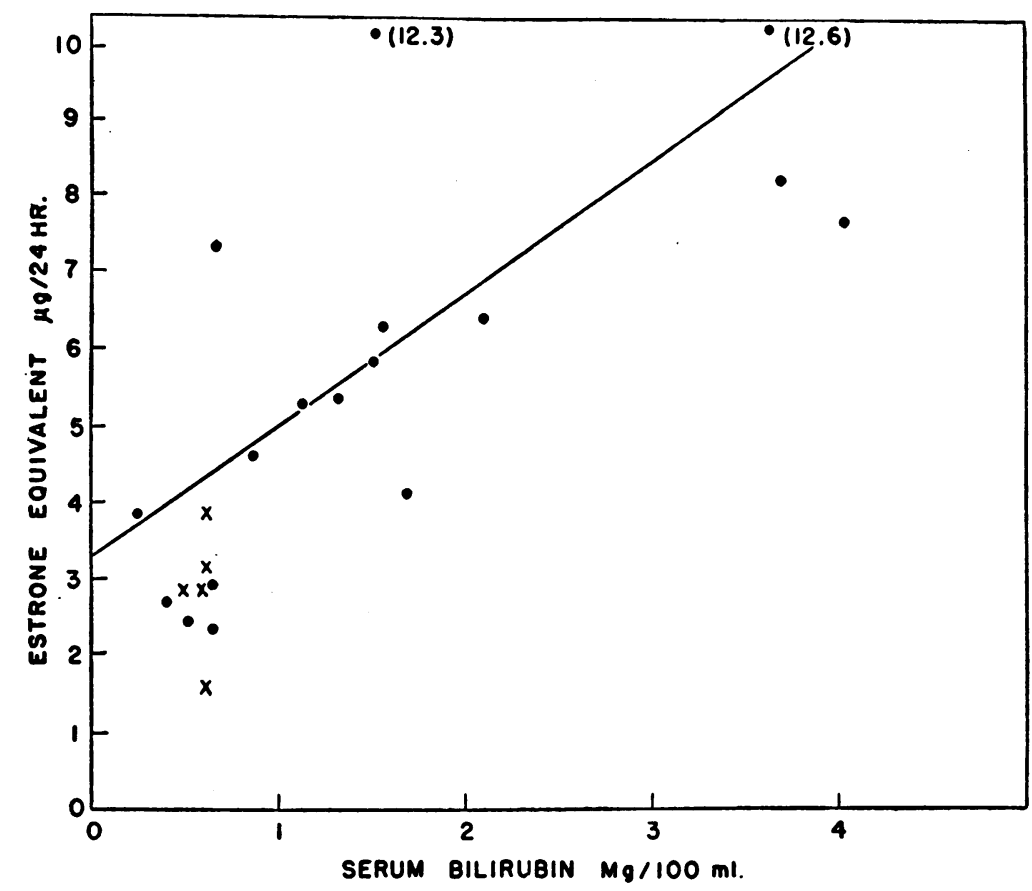

Fig. 2. The Relationship of the Urinary Excretion of Total Estrogens to Total Serum Bilirubin

The regression coefficient $(b=1.71$ with a standard error of 0.50$)$ and the correlation coefficient ( $r=0.65$ with a standard error of 0.19$)$ have been calculated from the values for patients with liver disease, indicated by $\bullet$. Values for estrogen excretion in men without liver disease are indicated by symbol $X$. Average normal serum bilirubin values are assumed for the control group. This relationship of estrogen excretion and total serum bilirubin is apparently limited to patients without severe jaundice (see text). 


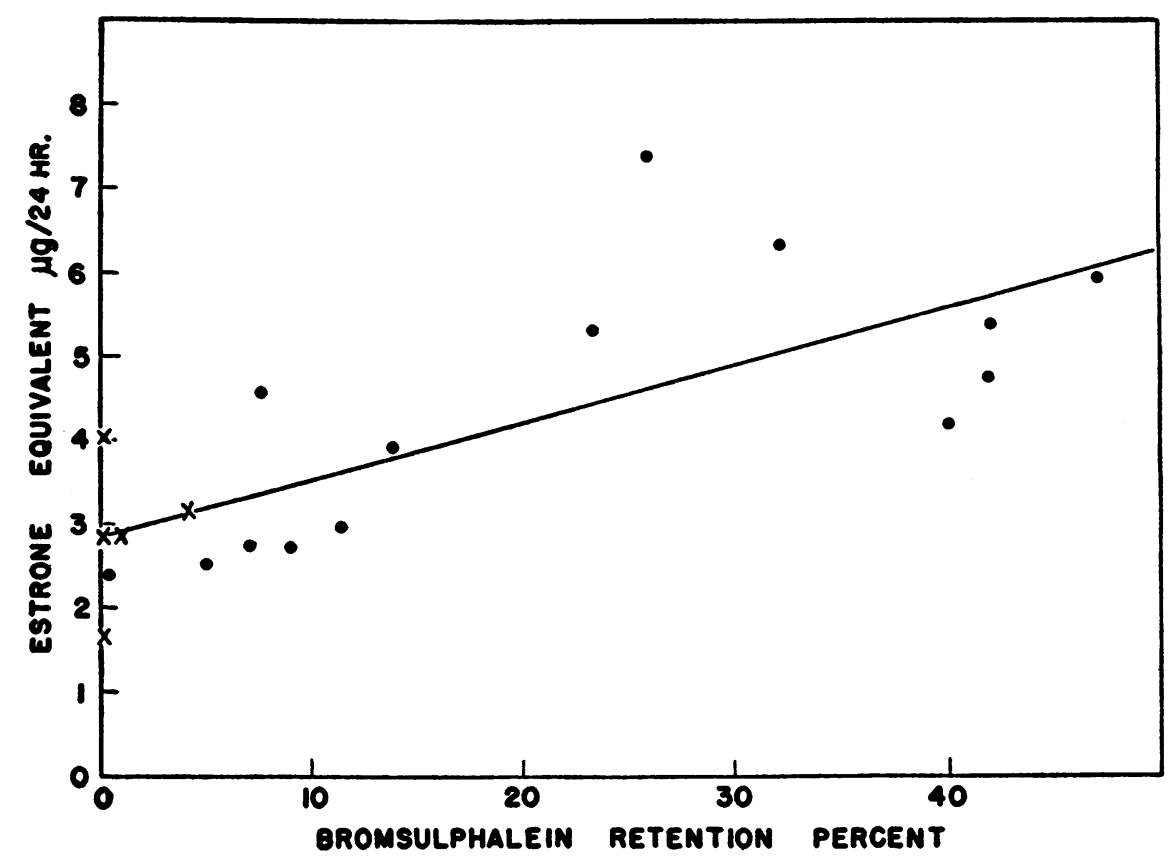

Fig. 3. The Relationship of the Urinary Excretion of Total Estrogens to Bromsulphalein Retention

The regression coefficient $(b=0.07$ with a standard error of 0.02$)$ and the correlation coefficient ( $r=0.70$ with a standard error of 0.21 ) have been calculated from the values for patients with liver disease, indicated by 0 . Values for total estrogen excretion in men without liver disease, indicated by $x$, are plotted along the vertical axis for comparison. In one of the normal men, a bromsulphalein retention test was performed because of a history of hepatitis four years before. This value was $4 \%$.

the total estrogen excretion was higher than the highest normal value. The patients with the most severe liver disease (grade IV) show the greatest excretion of free and total estrogens and the lowest values for 17-ketosteroid and gonadotrophins. Examination of the data shows that the increase in age of this group does not, in itself, account for the decreased 17-ketosteroids nor the elevated estrogens.

\section{Estrogen excretion and liver function tests}

All liver function tests were performed during the period of urine collection. Figures 2 and 3 show the highly significant correlation of urinary total estrogen excretion with the total serum bilirubin and bromsulphalein retention. This relationship is apparently valid only for lesser degrees of jaundice. Two observations were made in one patient (No. 10) one and five weeks after recovering from hepatic coma. During these periods, he had total serum bilirubin values of 34 and 11 mg./100 ml., and his total estrogen excretion was 2.6 and $4.7 \mu \mathrm{g} . / 24 \mathrm{hr}$. Three months later his serum bilirubin was $1.3 \mathrm{mg} . / 100 \mathrm{ml}$, and the total estrogen excretion was $5.4 \mu \mathrm{g} . / 24 \mathrm{hr}$. It is obvious that the regression demonstrated with mild elevations of serum bilirubin was not evident in this patient with severe jaundice. Furthermore, in a man with obstructive jaundice from carcinoma of the head of the pancreas, who is not included in this series, the total estrogen values were within normal limits when the total serum bilirubin was $20 \mathrm{mg} . / 100 \mathrm{ml}$. Both men were critically ill. The excretion of the free form of estrogens in the urine did not show a significant correlation with the serum bilirubin or bromsulphalein retention.

The relationship of total estrogen excretion to the cephalin-cholesterol flocculation, Kunkel gamma globulin, serum globulin, serum albumin, and thymol turbidity tests was also examined. No statistically significant relationship was found. 


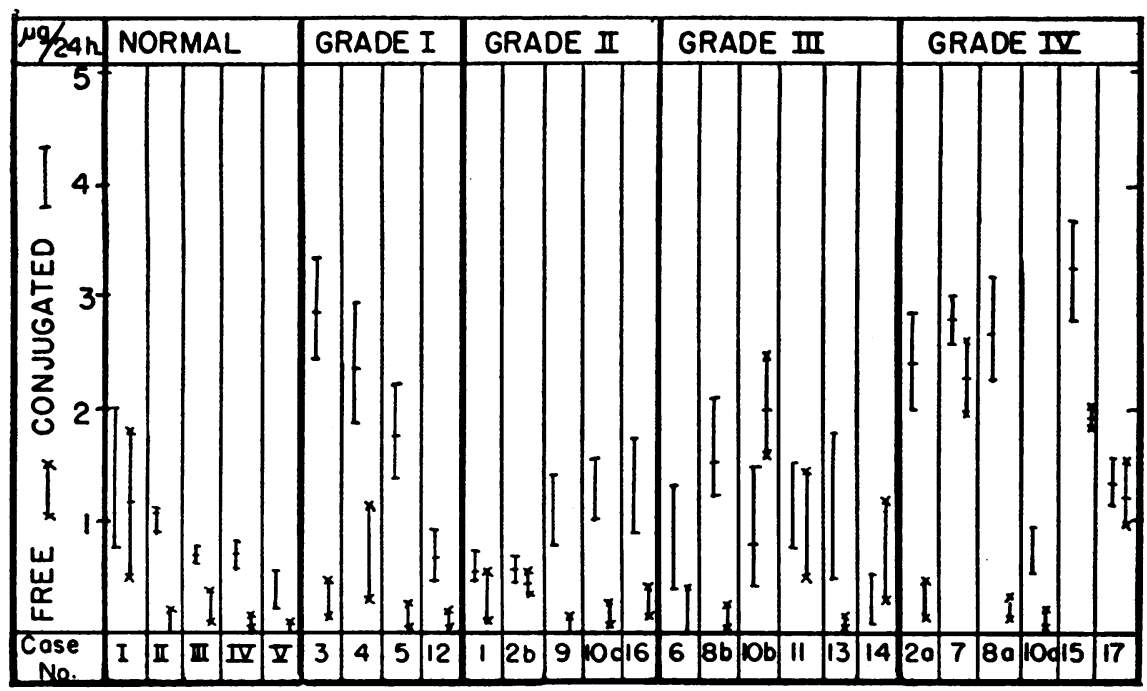

Fig. 4a. Urinary Excretion of Free and Conjugated "Estrone" in Normal Men AND MEN with LIVER Disease

Patients have been classified on the basis of a numerical evaluation of clinical, laboratory, and liver biopsy data. Grade IV indicates the most severe degree of liver disease. Results are arranged within each grade in order of increasing age of the patient. The sequence of repeated tests in patients No. 2, 8, and 10 is indicated by the letters $a, b$, and $c$. The extremes of the lines $\longrightarrow x$ represent the $95 \%$ confidence limits of the bioassays. The additional crossbar and $x-1-x$ represents the estimate of the potency by probit analysis (see Methods).

These findings, in association with the results presented in Table I, lead to the conclusion that within a limited range the increased estrogen excretion is more closely associated with evidence of impaired "excretory function" of the liver than with the other tests employed or the general severity of the disease as judged by the multiple criteria used in this study.

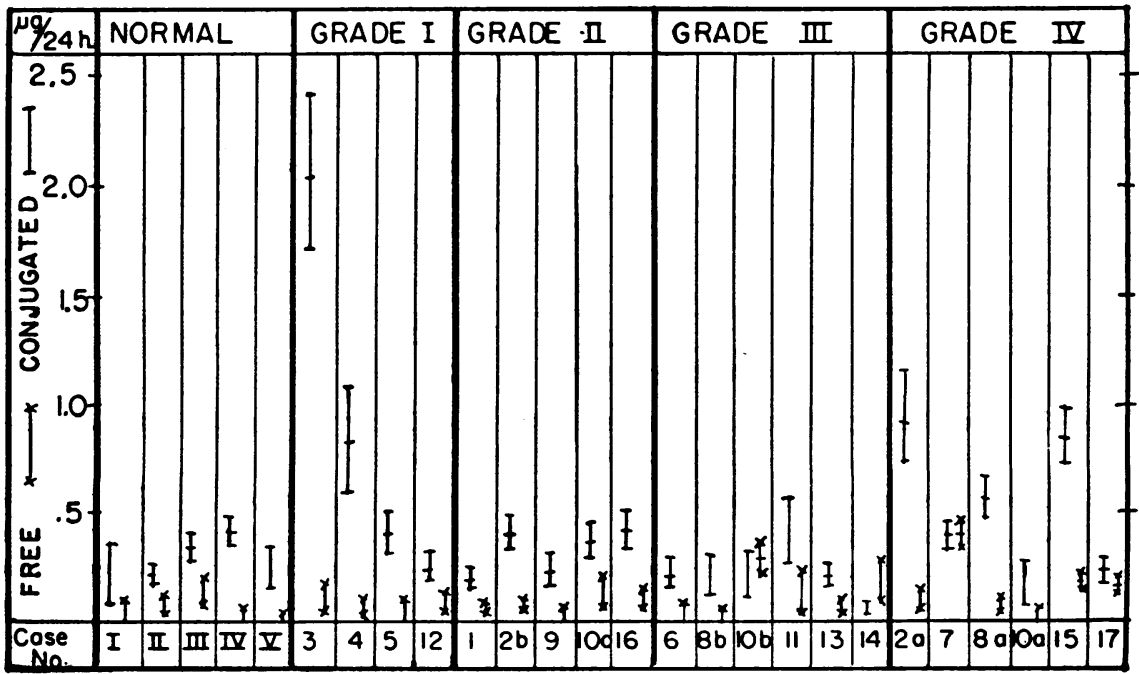

Fyc. 4b. Unmasy Exchetion of Fres and Conjugated "Estradiol" in Normal Men and Men with Liver Disease

See Figure $4 a$ for legend. 


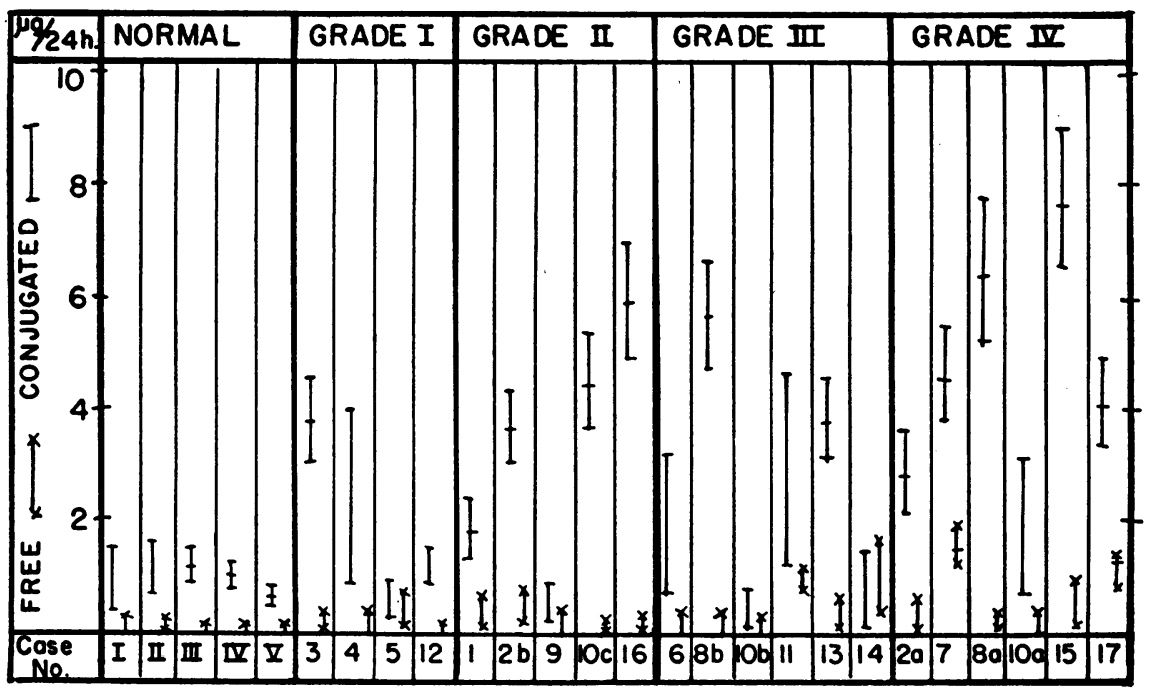

Fic. 4c. Urinary Excretion of Free and Conjugated "Estriol" in Normal Men and Men with Liver Disease

See Figure 4a for legend.

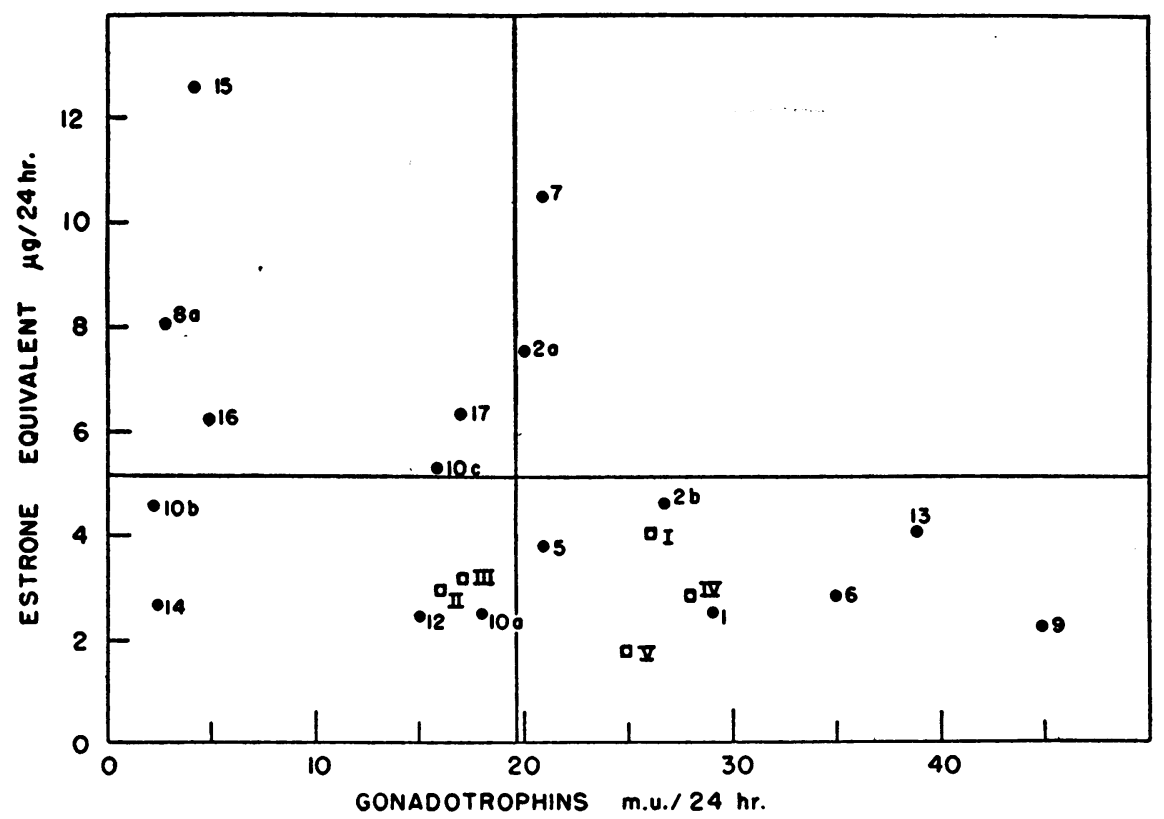

Fig. 5. The Relationship of Urinary Estrogen Excretion to the Urinary ExCRETION OF GONADOTROPHINS

The numbers indicate the patient and period number (see Table I). Normal controls are indicated by Roman numerals. The crossed lines indicate the mean estrogen and gonadotrophin values for the group. It is evident that gonadotrophin values more than slightly above the average are associated with estrogen values less than average for the group.

The error of the slope of the calculated regression line (not shown) is such that $P$ is slightly greater than 0.05 . Patient No. 14 had hemochromatosis. If this value is omitted because of clinical variation from the rest of the series, a "significant" regression is obtained. 


\section{Estrogen metabolism and liver disease}

Figure $4 \mathrm{a}, \mathrm{b}$, and $\mathrm{c}$ shows the excretion of the various estrogen fractions in normal men and men with liver disease. The conjugated form of one of the three fractions showed no overlap of confidence limits with the highest normal value in 20 instances. The conjugated form of "estrone" was increased as judged by this standard in five periods, "estriol" in 11, and "estradiol" in only four periods. The unconjugated form of "estrone," "estriol," and "estradiol" was increased in two, four, and two periods, respectively, a total of eight instances. In three instances, the unconjugated form of a particular fraction was increased without significant increase in the conjugated form. In five instances, there was a considerably greater increase in the conjugated form of the same fraction. Increase in the free form of one fraction was not necessarily associated with an increase in the free form of the other fractions. It is concluded from the above that increase in excretion of the conjugated form is, in general, more frequent and greater than that of the unconjugated form. Increases occur in all three fractions, but in the greatest number of patients and most markedly in both the free and conjugated forms of the estriol fraction.

\section{Inter-relationships of urinary hormone excretion}

Figures 5, 6, and 7 show the inter-relationships of urinary hormone excretion values. Figure 5 shows that in those periods exhibiting urinary gonadotrophin excretion greater than the group average, there were only two with estrogen excretion greater than average and nine with less than average estrogen excretion. Thus, high estrogen excretion was associated with gonadotrophin values less than, or only slightly above the average. The free estrogen excretion showed a similar relationship to gonadotrophin excretion (not charted).

Figure 6 shows that only one of the eight ketosteroid values above the average for the group was associated with estrogen excretion values greater than average. In other words, if the 17ketosteroid excretion was above average, the estrogen excretion tended to be below average.

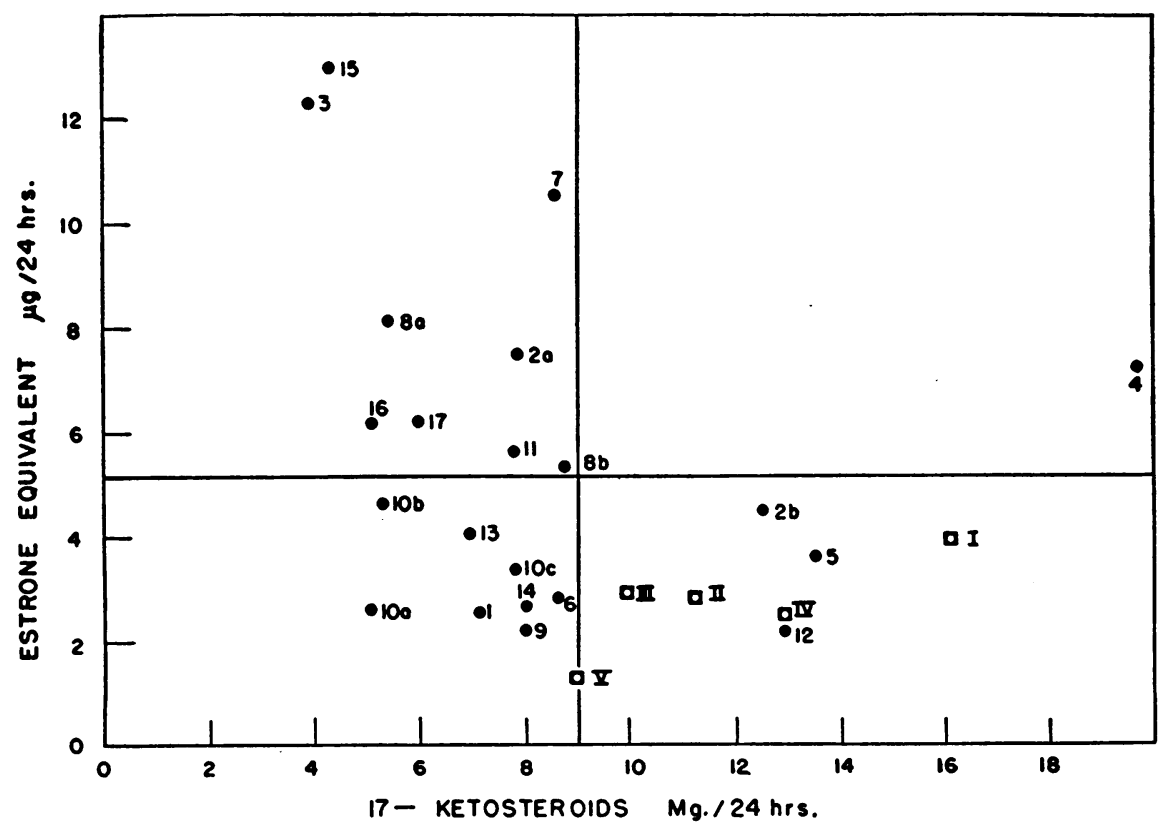

Fig. 6. The Relationship of Urinary Estrogens and 17-Ketosteroids

The numbers indicate the patient and period number (see Table I). Normal controls are indicated by Roman numerals. The crossed lines indicate the mean estrogen and 17-ketosteroid values for the group. Rank correlation analysis indicated a correlation that was not significant at the $P=0.05$ level but was at the $P=0.1$ level. 
Figure 7 shows that as the 17-ketosteroid values tended to be approximately average or above, the gonadotrophin values were also approximately average or above. The relationship of these two excretion values to each other is not as definite as their relationship to estrogen excretion.

The relationship of urinary hormone excretion to gynecomastia, cutaneous spider nevi, palmar erythema, testicular atrophy, and loss of libido

Gynecomastia. Figure 8 shows that the total estrogen excretion in the four men with stable or advancing gynecomastia was significantly greater than that for men with liver disease but without gynecomastia, the four men with regressing gynecomastia, and the normal controls. The four men with gynecomastia which disappeared within four months had a mean total estrogen excretion approximately the same as patients without gynecomastia. The increase in total estrogens in the men with stable or advancing gynecomastia was due to significant increases in the conjugated form of all three fractions. The unconjugated form was not significantly increased above that of patients with regressing gynecomastia, or none at all.

The mean and S.E. of the mean for the neutral 17 -ketosteroid excretion was $5.9 \pm 1.0 \mathrm{mg} . / 24 \mathrm{hr}$. in patients with stable or advancing gynecomastia; $7.6 \pm 1.8 \mathrm{mg} . / 24 \mathrm{hr}$. in patients with regressing gynecomastia; and $10.2 \pm 1.3 \mathrm{mg} . / 24 \mathrm{hr}$. in patients without gynecomastia. This relationship is reflected in the estrogen/17-ketosteroid ratio also shown in Figure 8 . The average gonadotrophic hormone excretion (not charted) was significantly reduced in the eight patients with gynecomastia to 11 m.u. $/ 24 \mathrm{hr}$. compared to 22 m.u. $/ 24 \mathrm{hr}$. for the controls and $28 \mathrm{~m} . \mathrm{u} . / 24 \mathrm{hr}$. for the patients without gynecomastia.

Cutaneous spider nevi. No significant relationship was found between the urinary excretion of total estrogens, free estrogens, 17-ketosteroids, or gonadotrophins and the presence of cutaneous spider nevi. The only significant increase is that of the free form of the estriol fraction in the 10

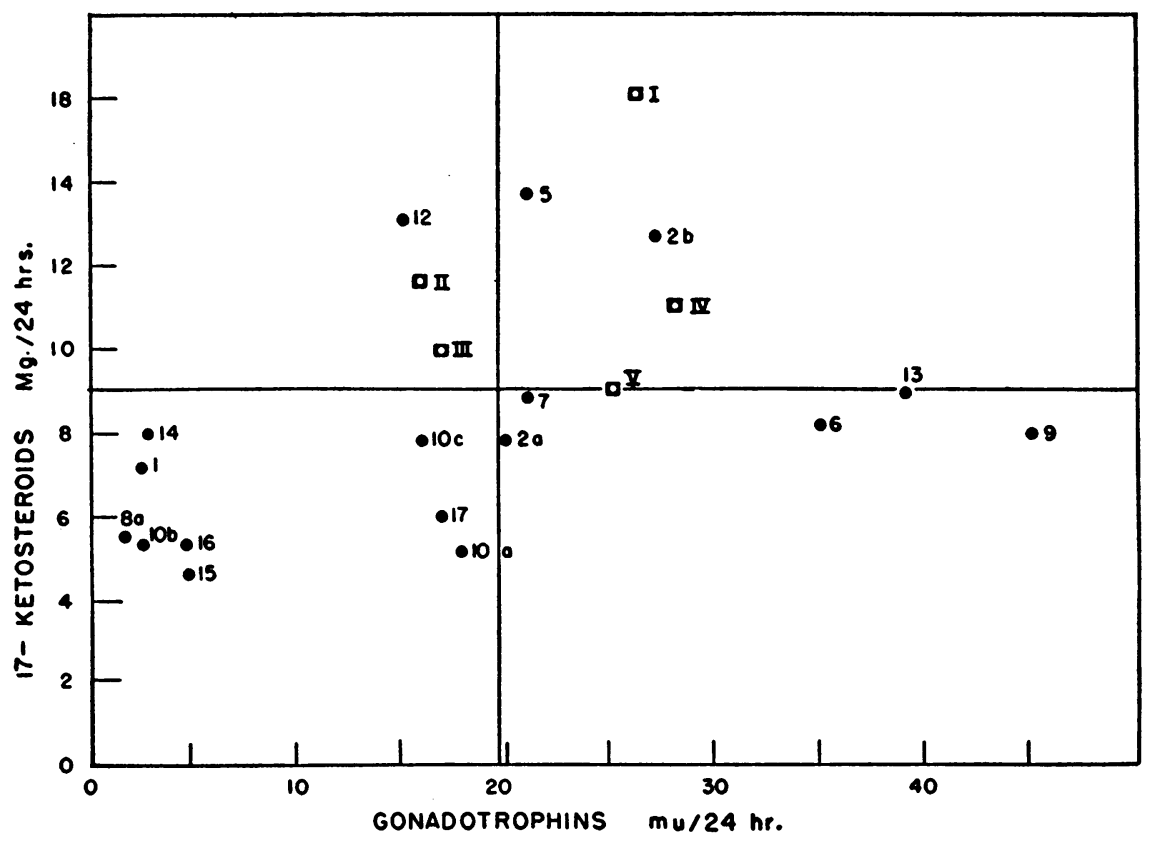

Fig. 7. The Relationship of Urinary 17-Ketosteroids and Gonadotrophins

The numbers indicate the patient and period number (see Table I). Normal controls are indicated by Roman numerals. The crossed lines indicate the mean 17ketosteroid and gonadotrophin values for the group. Rank correlation analysis indicated a correlation that was not significant at the $P=0.05$ level but was at the $P=$ 0.1 level. 

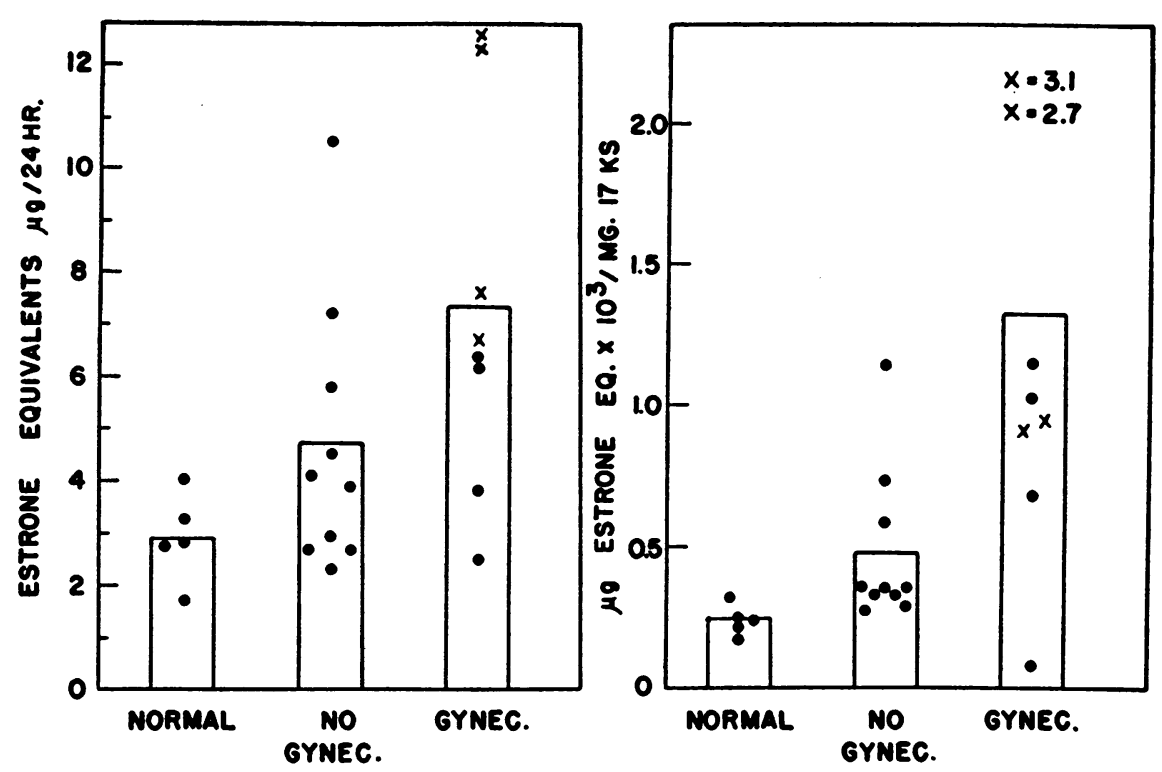

Fig. 8. The Relationship of the Urinary Excretton of Total Estrogens and tiIE Estrogen/17-Ketosteroid Ratio to Gynecomastia in MEN with Liver Disease

The first column in each section indicates the values in normal men, the second column that of men with liver disease without gynecomastia, and the third column men with liver disease and gynecomastia. In the third column, the symbol $x$ indicates individuals with stable or advancing gynecomastia, and $\bullet$ in the same column indicates patients with gynecomastia which disappeared within four months. Patient No. 2 with most marked gynecomastia, excreted $7.6 \mu \mathrm{g}$. of estrone equivalent per $24 \mathrm{hr}$. during period "a." Striking improvement occurred during aureomycin therapy. Six months later, the gynecomastia had disappeared. Urine excretion value at this time (period " $\mathrm{b}$ ") was $4.6 \mu \mathrm{g} . / 24 \mathrm{hr}$. and is included in the group with no gynecomastia. In the two other cases with multiple observations, the average values were used since there was no change in classification. In the three other patients with "stable or advancing gynecomastia" one patient (No. 3) continued to have three plus gynecomastia for at least seven months, another (No. 8) showed increasing gynecomastia between his two periods of urine collection. The third patient (No. 15) died four weeks after the observation was made.

patients with stable (or advancing) "skin spiders" when compared to that of the four patients without them or to the five normal controls as shown in Figure 9. The differences in the total free form and in the other fractions are not significant. Patient No. 7 had the most "skin spiders" and many of these showed arterial pulsations. This patient exhibited the highest excretion of the free form of all three fractions.

Palmar erythema. The three patients with palmar erythema did not exhibit significant variation in free or total estrogens, the estrogen fractions or 17-ketosteroid excretion from patients without this symptom. The gonadotrophin value in the one patient tested was normal.
Testicular atrophy and loss of libido. Figure 10 shows the relationship of the urinary hormone excretion to the presence of definite testicular atrophy (with loss of libido) and loss of libido (without detected testicular atrophy). A highly significant deviation from the normal values for gonadotrophin, 17-ketosteroids and estrogens is apparent for those men with loss of libido or testicular atrophy. A highly significant reduction in the gonadotrophic hormone excretion, and a decrease in total neutral 17-ketosteroid excretion of borderline significance, are found when this group is compared to patients without these symptoms. No significant differences between these two groups are found for total estrogens or 


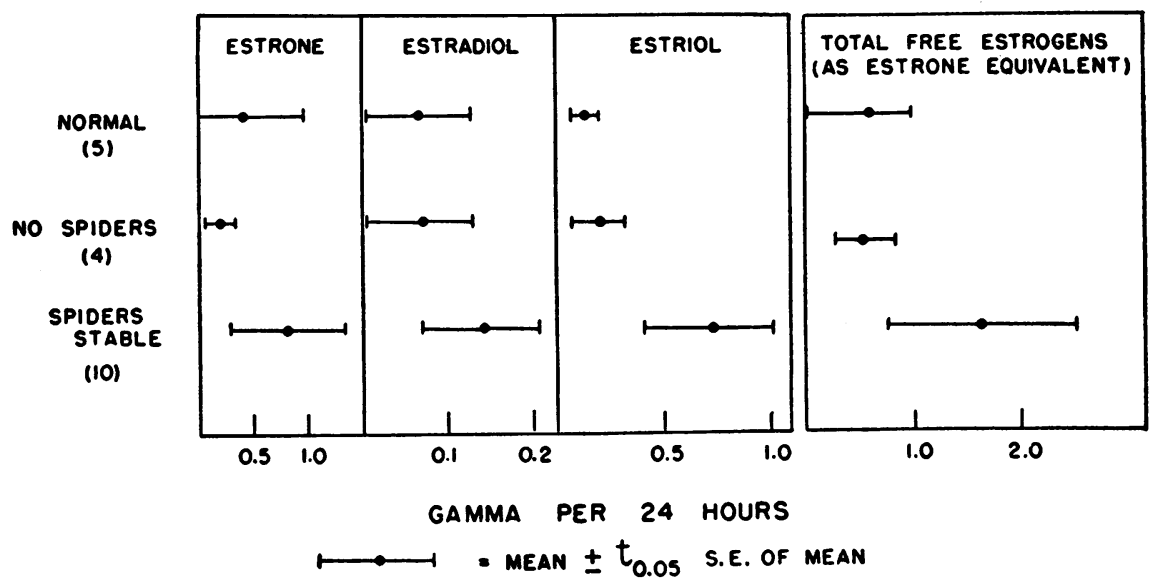

Fig. 9. Cutaneous Spider Nevi and Unconjugated Estrogen Fractions

The free "estriol" fraction was significantly greater in men with stable (or advancing) "skin spiders" than in normal individuals and patients without them. Three patients (values not charted) in whom "skin spiders" were present, but regressing, had approximately the same urinary excretion of free "estriol" as the patients without these lesions.

the free and conjugated forms of the "estrone," "estradiol," and "estriol" fractions (not shown in Figure 10). That age may be an important factor in these relationships is indicated by the average age of 33.3 years (range 22 to 46 ) in those without testicular atrophy or loss of libido; while those with one or both of these symptoms had an average age of 47.7 years ranging from

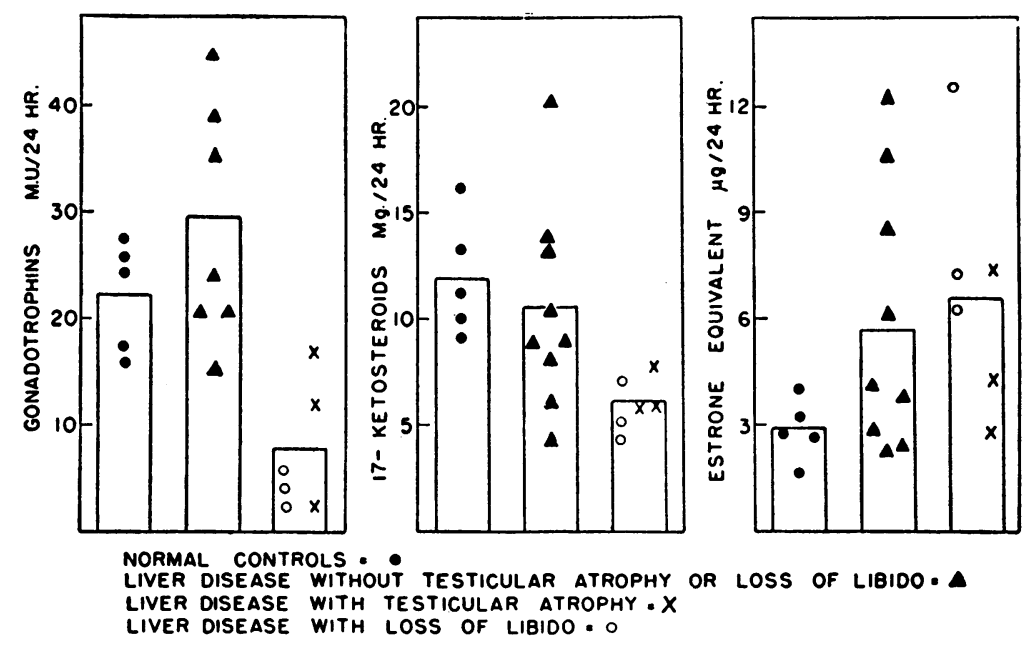

Fig. 10. Hormone Excretion and Testicular Atrophy and Loss of LIBIDO

In addition to the three patients with evident testicular atrophy and complete loss of libido, three other patients also had complete loss of libido. In two, scrotal edema prevented adequate estimation of testicular size and in the third, testes slightly smaller than the lower limits of normal were measured. These six patients have been included in a group, but differentiated by symbols as indicated. Three patients had analyses for more than one period. The data are pooled for each individual since there was no change in classification. 
35 to 60 years. In addition, men with these symptoms were, in general, more severely ill (grade III and IV) than those men without them.

\section{Miscellaneous observations}

The total neutral ketonic and non-ketonic fractions were determined on the ether extracts of the urine from five normal men and seven men with severe liver disease. The non-ketonic fractions were essentially the same for both groups while the mean total ketonic fraction for the men with liver disease was slightly less than one-half of that for normal men. This result is to be expected since the urinary excretion of 17-ketosteroids is depressed in severe liver disease.

The "free" fraction of neutral 17-ketosteroids was determined in 37 men with diffuse liver disease and five normal men. The difference between the means of the free fraction of the two groups was not significant, nor was it significant if only those patients with grade III or IV liver disease were compared with the normal individuals. These findings are similar to those of Williams, Cantarow, Paschkis, and Havens (22). These authors have also presented data indicating some decreased ability to conjugate the increased amount of 17 -ketosteroids produced by injection of testosterone propionate.

The urinary excretion of reducing corticoids was examined for periods of one to five days in 11 men and three women with varying degrees of diffuse liver disease. Seven of the 14 individuals had one or more 24 hour specimens with corticoid values greater than those for normal controls. Similar findings have been reported by Bongiovanni and Eisenmenger (23). The significance is unknown.

\section{DISCUSSION}

Hormone excretion and severity of liver disease

Clinical and pathological data have provided evidence in many patients with liver disease that there was probably an increase in the effective concentration of estrogens in the body fluids. The pioneer work of Glass, Edmondson, and Soll (2) afforded support for this concept by the finding of increased excretion of estrogens in the urine. Our findings, as well as those of Rupp, Cantarow,
Rakoff, and Paschkis (24) and Humm, Munson, and Salter (25) and others indicate an increase in total estrogen levels and decreased levels of neutral 17-ketosteroids in some patients with chronic liver disease, in so far as blood levels can be inferred from urinary excretion values. Although the most severe grade of liver disease was associated with the highest total estrogen and the lowest 17-ketosteroid excretion, the relationship of urinary excretion of these substances to the severity of the disease, as judged by our criteria, was not clear-cut (see Table I). Somewhat smaller increases in total estrogens and decreases in 17-ketosteroids have also been found in the acute stages of hepatitis, subsiding as the patient improved (26). The effect of liver disease on the excretion of unconjugated estrogens and estrogen fractions is discussed below.

\section{Correlation of total estrogen excretion with liver function}

Figure 1 shows some mechanisms possibly involved in ridding the body of active estrogens. Increased production of estrogens seems improbable as an explanation for the estrogenic effects noted in some patients with liver disease, but remains a possibility. Impaired excretion or destruction, or both, seems to be a more probable explanation. The effect of conjugation on activity is discussed below. Figures 2 and 3 demonstrate the positive linear correlation of urinary estrogen excretion with serum bilirubin and bromsulphalein retention over a limited range. Since these tests are considered to be a measure of "excretory function" of the liver, and since there is no significant correlation of estrogen excretion with other liver function tests nor as distinct a correlation with the general severity of the disease, it seems probable that the increased urinary excretion is, in part, due to decreased excretion through the biliary tract or to a decrease of some other functions of the liver reflected by these tests. It is important to note that this relationship is demonstrated only for patients with lesser degrees of jaundice and was not present in two patients with severe jaundice. Decreased production of estrogen in these severely ill men is suggested as a probable explanation for this finding.

The biliary excretion of estrogens and their 
esters has been recently reviewed $(3,10)$. Biliary excretion has been demonstrated in laboratory animals and in man by bio-assay and chemical methods. Estrogenic activity has been found in the feces of normal men in amounts up to seven times that found in the urine $(27,28)$. In contrast, Gallagher, Fukushima, Barry, and Dobriner (29) have failed to find free or conjugated 17ketosteroids in feces of normal men. Recent work using estrogens labeled with radioactive halogens has shown that a high proportion of such compounds are excreted by way of the bile duct in both the mouse (10) and man (30). The quantities of radioactive material found in feces are considerably greater than would be expected from bio-assays and suggest that selective excretion of the halogenated compounds may have occurred or that inactive or unextracted estrogens are present in the feces (10). Thus, it seems possible that failure of excretion of estrogens through the biliary tract may account, in part, for the increased urinary excretion found in some patients with liver disease.

\section{Excretion of estrogen fractions and the free and conjugated forms}

In this discussion of the "estrone," "estradiol," and "estriol" fractions, it must be remembered that separation of these three steroids is not absolute even by the best partition methods $(9,10)$. Our single experiment (described in Methods) would support this conclusion; especially for the small amounts of estrogens found in male urine. Nevertheless, this and the partition studies of others $(9,10)$ make it clear that the major activity of a fraction may be properly ascribed. It will be noted that our values for the estrogen fractions in the normal men are less than those reported by Pincus (31). This is presumably due to difference in preservation, hydrolysis, and extraction technics.

In the men with liver disease, the major increase occurred in the free and conjugated form of the estriol fraction. It seems unlikely that hepatic disease would be associated with increased conversion of estradiol and estrone to estriol. In fact, there is some evidence from studies on a man with cirrhosis of decreased conversion to estriol (32). Since nothing is known of the type of estrogen produced by the adrenal and testes of the human male, the significance of this finding is not clear.

Only six of the 17 patients in our series showed an increase in the unconjugated estrogens. This agrees with the finding of Rupp and associates (24), but is a smaller proportion than that found by Glass, Edmondson, and Soll (2). During the past 10 years, it has become abundantly evident that hydrolysis of steroid conjugates may occur if urine is allowed to remain at room temperature, and even to some extent at $4^{\circ} \mathrm{C}$. Therefore, this possibility must be considered in any study involving analysis of the free form. We believe that our findings represent a true difference in values between patients with liver disease and the normal controls, since the urine specimens were handled in a similar fashion for both groups, care being taken to decrease the possibility of spontaneous hydrolysis.

In discussing the physiological role of the free form of estrogens and of estriol, it seems proper to reconsider the concept that the conjugated steroids and estriol are considerably "less active" (8). These ideas were based on data primarily derived from assays employing subcutaneous or intramuscular injections. Differences in rates of absorption from the site of injection is a recognized factor in the effect of the various forms of estrogen on the target tissues and for this reason this technic does not measure the true potency at the level of the target tissue. Intravaginal assays are believed to afford a better comparison of potency at the tissue level. Robson and Adler have demonstrated the local effectiveness of estriol glucuronide by instilling it into one section of the surgically made double vagina in mice (6). Furthermore, Emmens' (7) assays of certain esterified and non-esterified estrogens, by intravaginal technic show but little, if any, difference in activity of the two forms. The intravaginal assay of estrogens absorbed on various proteins demonstrates that estradiol is only slightly more active than estrone and estriol, which have the same potency (33). However, we are unaware of comparative assays of the free form and the glucuronide of estrone, estradiol, and estriol done by the multiple dose intravaginal technic. Since many tissues in the body show glucuronidase activity, 
it seems probable that conjugation with glucuronic acid or lack of it is not an important factor in determining estrogen activity for such tissues (34). Therefore, it is believed that the production of the conjugated forms and of estriol from estrone or estradiol, should no longer be considered important mechanisms for decreasing the activity of estrogens. Furthermore, we have not found a significant correlation of any physiological effect of estrogen with the urinary excretion of the total free fraction. The relationship of the free estriol fraction to the presence of cutaneous spider nevi is discussed later.

\section{Inter-relationships in urinary excretion of hormones}

The relationship of urinary 17-ketosteroid and gonadotrophin excretion (Figure 7) in these patients is supporting evidence of the role of gonadotrophic hormones in the production of 17-ketosteroids in males. It seems probable that the large proportion of urinary 17-ketosteroid formed from adrenal cortical steroids partially obscures this relationship. The relatively lower gonadotrophin excretion with high excretion levels of estrogen, as demonstrated in Figure 5, is also to be expected, since there is considerable physiological data supporting the concept that increased levels of blood estrogen are associated with decreased gonadotrophin secretion. It is of interest that relatively slight increases of estrogen excretion are associated with apparent decrease in gonadotrophin excretion and there are apparently even more definite relationships with 17 -ketosteroid excretion (Figure 6).

\section{Correlation of hormone excretion with clinical manifestations}

The increased excretion of total estrogens and decrease in 17-ketosteroids in association with stable or advancing gynecomastia in men with liver disease needs but little comment. The apparent lack of correlation in some investigations $(24,35)$ may, in part, be due to regressing gynecomastia being included in the series. In four of our eight cases of gynecomastia, this symptom disappeared within four months of the urine collection period. In two of these men, the estrogen excretion was normal, and in two, it was only moderately elevated (Figure 8). Thus, observations on hormone-tissue relationships may be confusing unless the condition of the target tissue at the time of the urine collection is known. There was no relationship between the free form of estrogen and the presence of gynecomastia. This does not support the thesis of Glass, Edmondson, and Soll (2) that gynecomastia is due to an increase in the free form of estrogens.

The possibility exists that the tissue androgen level may play a role in the production of gynecomastia. It has been demonstrated by Mühlbock (36) that testosterone may inhibit the growth of breast tissue, ordinarily produced by estrone in the castrate male rat. Recent observations in two patients with adrenal cortical tumors secreting large amounts of estrogen and androgens without gynecomastia and in two patients with adrenal tumors and exhibiting gynecomastia and high urinary estrogen values with normal 17-ketosteroids, suggest that this may also be true, to some extent, in man (37). With this in view, the estrogen-ketosteroid ratio was calculated and charted in Figure 8. It will be noted that there was a greater difference between those patients having gynecomastia and liver disease, and those with liver disease but without gynecomastia when charted in this fashion, than when these groups are compared on the basis of total estrogen excretion. The appearance of gynecomastia during testosterone administration, and many other unexplained observations (38) serve to emphasize the difficulties in the over-simplified considerations detailed above.

There was no correlation between the presence of cutaneous spider nevi and the urinary excretion of total estrogens. However, clinical evidence (39) strongly supports some role of estrogens in the production of cutaneous spider nevi, but the peculiar distribution of "skin spiders" and other considerations indicate that other factors than estrogens are probably of importance in the production of these lesions. Our data show a significant correlation between the presence of non-regressing "skin spiders" and the urinary excretion of estriol in the free form. This surprising finding suggests that the free form of estriol may stimulate growth of certain blood vessels under special conditions. It also suggests 
the absence of glucuronidase activity in the blood vessels of the skin.

Testicular atrophy and loss of libido in patients with liver disease is associated with significantly lower values of urinary gonadotrophins and a decrease of borderline statistical significance in the 17-ketosteroids. Although the method employed to measure "gonadotrophins" in this study is believed (18) to measure primarily the effect of follicle stimulating hormone (FSH), it is probable that the presence of some interstitial cell stimulating hormone (ICSH) is necessary for activity. Thus, suggestive evidence is afforded that the decreased 17 -ketosteroid excretion in these men is due, in part, to decreased production of androgens by the Leydig cells of the testes as a result of decreased gonadotrophic hormone secretion by the pituitary. The effect of chronic illness on adrenal cortical function must also be considered. The decreased androgens may, in this instance, be an important factor in loss of libido. The stimulating effect of intramuscular injection of testosterone upon sexual desire in men with liver disease has been briefly noted by Rosenak, Moser, and Kilgore (40). The testicular atrophy may be attributed to the decrease in gonadotrophins. The relative importance of $\mathrm{FSH}$ and androgens in support of the tubular tissue of the adult human testis is obscure. From inspection of the data, it seems likely that the increase in circulating estrogens (presumed from the urinary excretion values) is not the only factor responsible for inhibition of gonadotrophin production. Age and impaired nutrition may play a role.

\section{SUM MARY}

The urinary excretion of the unconjugated and conjugated forms of the "estrone," estradiol," and "estriol" fractions, as well as neutral 17ketosteroids and gonadotrophins, has been determined for one or more three to 22 day periods in five normal men and 17 men with diffuse hepatic disease. The results support the concept of disturbed hormone metabolism as a cause for some of the symptoms of diffuse hepatic disease and suggest that decreased biliary excretion may, in part, be responsible for the increased urinary excretion of estrogens. The main findings are listed below :
Estrogens. (1) Total estrogen excretion was increased in 11, and the unconjugated form in six of the patients. The group with most severe liver disease exhibited the highest excretion of both conjugated and unconjugated forms of estrogens. (2) The excretion of total estrogens showed a highly significant correlation with bromsulphalein retention and the total serum bilirubin values in patients with mild jaundice. Two patients with severe jaundice did not show increased estrogen excretion. There was no significant correlation with other tests of liver function. (3) The excretion of total estrogens (but not that of the unconjugated form) was significantly increased in the four patients with advancing or stable gynecomastia in comparison to that of patients with regressing or no gynecomastia. (4) In general, a high total estrogen excretion was associated with less than average gonadotrophin and 17-ketosteroid excretion. (5) Both the conjugated and unconjugated forms of "estriol" were increased to a greater extent and more frequently than "estrone" or "estradiol." (6) The excretion of unconjugated "estriol" was significantly increased in the patients exhibiting stable or advancing cutaneous spider nevi.

17-Ketosteroids. The 17-ketosteroid excretion was less than normal in 14 of the 17 patients and was decreased in the four men with stable or advancing gynecomastia and the six men with testicular atrophy and/or loss of libido when compared to patients without these symptoms.

Gonadotrophins. Gonadotrophins were significantly decreased in the six patients with testicular atrophy and/or complete loss of libido.

\section{ACKNOWLEDGMENTS}

The technical assistance of Walter Applin, Emma D. Kuen, Irmgaard Landolt, Elizabeth Ransome, and Gloria Allen is gratefully acknowledged. We also wish to thank Dr. E. Douglass Burdick of the Department of Statistics for his advice; Dr. William Ehrich for his aid in the evaluation of liver biopsies; Dr. Victor Sborov, Director of the Army Hepatic and Metabolic Center; and Dr. Lewis L. Engle of the Massachusetts General Hospital for his advice regarding certain extraction procedures. Our thanks are also due to Dr. F. C. Wood and Dr. F. D. $W$. Lukens for reviewing the manuscript. 


\section{REFERENCES}

1. Lloyd, C. W., and Williams, R. H., Endocrine changes associated with Laennec's cirrhosis of the liver. Am. J. Med., 1948, 4, 315.

2. Glass, S. J., Edmondson, H. A., and Soll, S. N., Sex hormone changes associated with liver disease. Endocrinology, 1940, 27, 749.

3. Paschkis, K. E., and Rakoff, A. E., Some aspects of the physiology of estrogenic hormones, in Recent Progress in Hormone Research, edited by Pincus, G. Academic Press, Inc., New York, 1950, Vol. V, p. 115.

4. Cohen, S. L., Marrian, G. F., and Odell, A. D., Oestriolglucuronide. Biochem. J., 1936, 30, 2250.

5. Twombley, G. H., and Taylor, H. C., Jr., Inactivation and conversion of estrogens in vitro by liver and other tissues from human cancer patients and from mice of strains susceptible to mammary carcinoma. Cancer Research, 1942, 2, 811.

6. Robson, J. M., and Adler, J., Site of action of estrogen. Nature, 1940, 146, 60.

7. Emmens, C. W., Hormone Assay. Academic Press, Inc., New York, 1950, p. 406.

8. Jailer, J. W., The metabolism of estrogens: review. J. Clin. Endocrinol., 1949, 9, 557.

9. Heard, R. D. H., The metabolism of estrogens, Part One; in Recent Progress in Hormone Research, edited by Pincus, G. Academic Press, Inc., New York, 1949, Vol. IV, p. 25.

10. Heard, R. D. H., and Saffran, J. C., The metabolism of estrogens, Part Two. Ibid., p. 43.

11. Wilson, D., Grauer, R. C., and Saier, E., A simplified continuous extractor for estrogens and androgens. J. Lab. \& Clin. Med., 1940, 26, 581.

12. Friedgood, H. B., Garst, J. B., and Haagen-Smit, A. J., A new method for the separation of androgens from estrogens and the partition of estriol from the estrone-estradiol fraction with special reference to identification and quantitative microdetermination of estrogens by ultraviolet absorption spectrophotometry. J. Biol. Chem., 1948, 174, 523.

13. Mather, A., Distributions of estrogens between immiscible solvents. J. Biol. Chem., 1942, 144, 617.

14. Simon, L. E., Engineers' Manual of Statistical Methods. John Wiley \& Sons, Inc., New York, 1941.

15. Emmens, C. W., Reports on biological standards. V. Variables affecting the estimation of androgenic and oestrogenic activity. Medical Research Council. His Majesty's Stationary Office, London, 1939, Special Report. Series No. 234.

16. Emmens, C. W., Principles of Biological Assay. Chapman \& Hall, Ltd., London, 1948, p. 139.

17. Mainland, D., Statistical methods in medical research. I. Qualitative statistics (enumeration data). Canad. J. Research, 1948, E. 26, 1.

18. Klinefelter, H. F., Jr., Albright, F., and Griswold, G. C., Experience with a quantitative test for nor- mal or decreased amounts of follicle stimulating hormone in the urine in endocrinological diagnosis. J. Clin. Endocrinol., 1943, 3, 529.

19. Holtorff, A. F., and Koch, F. C., Colorimetric estimation of 17-ketosteroids and their application to urine extracts. J. Biol. Chem., 1940, 135, 377.

20. Heard, R. D. H., Sobel, H., and Venning, E. H., The neutral lipid-soluble reducing substances of urine as an index of adrenal cortical function. J. Biol. Chem., 1946, 165, 699.

21. Snedecor, G. W., Statistical Methods Applied to Experiments in Agriculture and Biology. The College Press, Inc., Ames, Iowa, 1946, 4th edition.

22. Williams, T. L., Cantarow, A., Paschkis, K. E., and Havens, W. P., Jr., Urinary 17-ketosteroids in chronic liver disease. Endocrinology, 1951, 48, 651.

23. Bongiovanni, A. M., and Eisenmenger, W. J., Adrenal cortical metabolism in chronic liver disease. J. Clin. Endocrinol., 1951, 11, 152.

24. Rupp, J., Cantarow, A., Rakoff, A. E., and Paschkis, $\mathrm{K}$. E., Hormone excretion in liver disease and in gynecomastia. J. Clin. Endocrinol., 1951, 11, 688.

25. Humm, F. D., Munson, P. L., and Salter, W. T., A comparison of urinary estrogens determined biologically and of "estroids" determined chemically. Endocrinology, 1951, 48, 225.

26. Gilder, H., and Hoagland, C. L., Urinary excretion of estrogens and 17-ketosteroids in young adult males with infectious hepatitis. Proc. Soc. Exper. Biol. \& Med., 1946, 61, 62.

27. Kemp, T., and Pedersen-Bjergaard, K., Uber die Aufnahme und Ausscheidungsverhaltnisse des Follikulins beim Menschen. Endokrinologie, 1933, 13, 156.

28. Siebke, H., and Schuschania, P., Ergebnisse von Mengenbestimmungen des Sexualhormons; Sexualhormon in Harn und Kot bei regelmässigem mensuellem Zyklus, Zyklusstörungen und bei Hormontherapie. Zentralbl. f. Gynäk., 1930, 54, 1734.

29. Gallagher, T. F., Fukushima, D. K., Barry, M. C., and Dobriner, K., Studies with isotopic steroid hormones, in Recent Progress in Hormone Research, edited by Pincus, G. Academic Press, Inc., New York, 1951, Vol. VI, p. 131.

30. Twombley, G. H., and Schoenewaldt, E. F., The metabolism of radioactive dibromoestrone in man. Cancer, 1950, 3, 601.

31. Pincus, G., The analysis of human urine for steroid substances. J. Clin. Endocrinol., 1945, 5, 291.

32. Stealy, C. L., and Stimmel, B. F., Further studies on the metabolism of therapeutic doses of natural estrogens in human subjects. J. Clin. Endocrinol., 1948, 8, 67.

33. Biggers, J. D., Observations on the intravaginal assay of natural estrogens using aqueous egg albu$\min$ as the vehicle of administration. J. Endocrinol., 1951, 7, 163. 
34. Fishman, W. H., and Anlyan, A. J., Beta-glucuronidase activity in human tissues; some correlations with the processes of malignant growth and with the physiology of reproduction. Cancer Research, $1947,7,808$.

35. Pincus, I. J., Rakoff, A. E., Cohn, E. M., and Tumen, J. J., Hormonal studies in patients with chronic liver disease. Gastroenterology, 1951, 19, 735.

36. Mühlbock, O., Response of mammary glands of male mice to estrone. Experiments with strains of dif- ferent genetic constitution. Acta. Brev. Neerland., 1948, 16, 1.

37. Dohan, F. C., Rose, E. R., Richardson, E. M., Zintel, H., Dyer, W. W., and Eiman, J., Unpublished data. 38. Burrows, H., Biological Action of Sex Hormones. University Press, Cambridge, 1949, 2nd edition.

39. Bean, W. B., The cutaneous arterial spider: a survey. Medicine, 1945, 24, 243.

40. Rosenak, B. D., Moser, R. H., and Kilgore, B., Jr., Treatment of cirrhosis of the liver with testosterone propionate. Gastroenterology, 1947, 9, 695. 